Proc. Estonian Acad. Sci. Geol., 2003, 52, 2, 98-112

\title{
Paralogania from the Rootsiküla (Wenlock) and Paadla (Ludlow) stages of Estonia
}

\author{
Tiiu Märss
}

Institute of Geology, Tallinn Technical University, Estonia pst. 7, 10143 Tallinn, Estonia; marss@gi.ee

Received 3 May 2002, in revised form 18 June 2002

\begin{abstract}
Paralogania species in the Rootsiküla (Wenlock) and Paadla (Ludlow) stages from Saaremaa Island, Estonia, were re-studied. Extremely well preserved scales of P. martinssoni (Gross) were described from Silma Cliff (Himmiste Beds of the Paadla Stage) and compared with the scales from Vesiku Brook (Vesiku Beds of the Rootsiküla Stage), the type locality of the species. Paralogania kaarmisensis sp. nov. was established on the basis of relatively large, strongly elongate scales carrying a row of very fine spines laterally of the crown; the scales have one to two fine oblique ridges above the row of spines. The new species has a short range in the Phlebolepis elegans Biozone (Ludlow, Upper Silurian).
\end{abstract}

Key words: Paralogania, Thelodonti, Agnatha, Wenlock, Ludlow, Silurian, Estonia.

\section{INTRODUCTION}

The thelodont genus Paralogania Karatajūtè-Talimaa, 1997 is widespread over the northern hemisphere and has been listed from the East European Platform, Severnaya Zemlya Archipelago, British Isles, Greenland, and northern Canada (Baillie-Hamilton Island and Mackenzie Mountains). Today, eleven Paralogania species are known from the Llandovery (Silurian) up to the Lower Lochkovian (Lower Devonian).

Paralogania (= Logania) martinssoni was established by Gross (1967) on scales from the Vesiku Brook outcrop, Saaremaa Island. As the material was rather scarce, he published an additional description of scales of that species from the Halla Beds of the Gothemshammar locality, Gotland Island, Sweden (Gross 1968). Later, Karatajūtè-Talimaa (1978) and Märss (1986) found this species from several cores of the East Baltic and North Timan, and outcrops of the Severnaya Zemlya islands. Karatajūtè-Talimaa (1997) erected a new genus Paralogania and placed $P$. $(=L$.) martinssoni into it.

The scales of $P$. martinssoni from sample 2 TM86, Silma cliff on Saaremaa Island (Himmiste Beds of the Paadla Stage, Ludlow), are perfectly preserved, 
which is a very rare phenomenon (see also the scales of P. ludlowiensis (Gross) from Linley Brook, Shropshire, Britain (Miller \& Märss 1999)). The residue contains scale varieties, for example the head and transitional scales which have not been described earlier (Gross 1967, 1968; Karatajūtė-Talimaa 1978; Märss 1986; Soehn et al. 2000). The scales show the true size and morphology of the anterior projection of the base and extremely fragile posterior spines of the crown.

At the same stratigraphical level (Himmiste Beds of the Paadla Stage) on Saaremaa Island (Fig. 1) scales of a Paralogania occur, which do not fit with

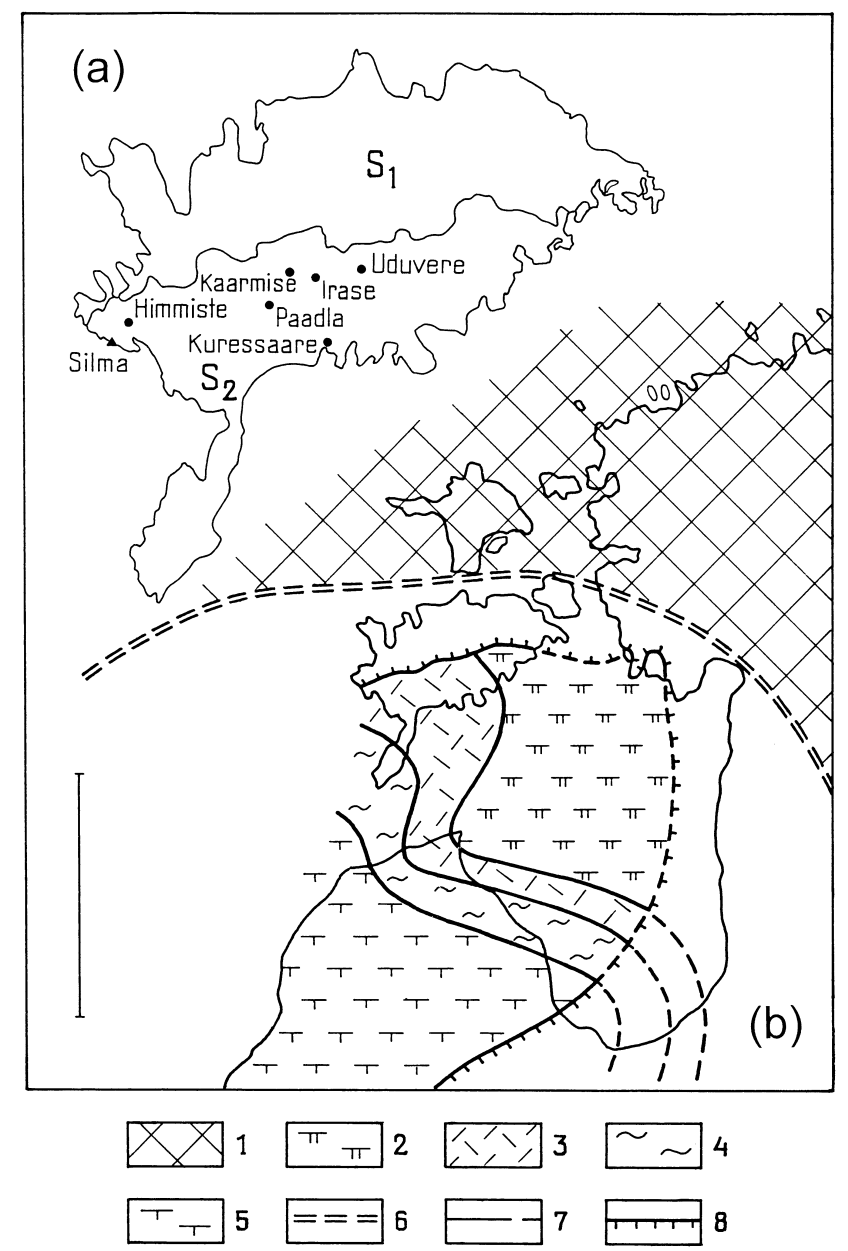

Fig. 1. (a) Location of the outcrop (triangle) and core sections (black dots) on Saaremaa Island, Estonia. $S_{1}$ and $S_{2}$, distribution of Lower and Upper Silurian rocks, respectively. The map follows Suuroja et al. (1997). (b) Distribution of deposits and facies belts of the middle part of the Paadla Stage. 1, presumable land; 2, lagoonal dolomitic mud; 3, pelletal-skeletal sand and silt; 4, bioclastic calcareous mud; 5, calcareous-argillaceous mud; 6 , shoreline; 7, facies boundary; 8 , boundary of the present distribution of rocks. The map follows Nestor \& Einasto (1997, p. 203, fig. 149). Scale bar for (b) is $100 \mathrm{~km}$. 
the definition of P. martinssoni (Gross, 1967) because of their larger size, very elongate shape, very fine spines, and one to two fine longitudinal ribs above the spines posterolaterally of the crown in some scales. These scales come from nodular argillaceous fine grainstones and shallow-water Eurypterus-dolostones, calcareous and argillaceous marlstones, and dolomitic marls. This Paralogania is usually associated with other thelodonts such as Thelodus laevis (Pander), T. carinatus (Pander), Paralogania martinssoni (Gross), Phlebolepis elegans Pander, osteostracans Tremataspis milleri Patten, Tr. mammillata Patten, Procephalaspis sp., anaspids Vesikulepis funiformis? Blom, Märss \& Miller, Silmalepis erinacea Blom, Märss \& Miller, and Schidiosteus mustelensis Pander (for anaspids see Blom et al. 2002); very rare acanthodian scales may occur in a few samples. The scales that belong to the new species have also been found from the upper Bringewood (Gorstian) and lower part of the Leintwardine Group (Ludfordian) of Welsh Borderland (Märss \& Miller accepted), and UstSpokoinaya Formation (Ludlow), Severnaya Zemlya Archipelago (Märss \& Karatajūtè-Talimaa 2002, fig. 3G-I, L).

The aim of this work is to describe perfectly preserved scales of Paralogania martinssoni (Gross), compare them with the material from the Vesiku Brook locality, and establish a new species of Paralogania. The described scale collection is housed in the Institute of Geology at Tallinn Technical University under the registration number GIT 346 + scale number.

\section{SYSTEMATIC DESCRIPTION}

Class AGNATHA Cope, 1889

Subclass THELODONTI Kiaer, 1932

Order SHIELIIFORMES Märss, Wilson \& Thorsteinsson, 2002

Genus Paralogania Karatajūtè-Talimaa, 1997

Type species. Logania kummerowi Gross, 1967.

Diagnosis. See Karatajūtè-Talimaa 1997, p. 13.

Species content. Paralogania martinssoni (Gross, 1967); P. ludlowiensis (Gross, 1967); P. kummerowi (Gross, 1967); P. borealis (Karatajūtè-Talimaa, 1978); P. foliala Blom, 1999; P. consimilis Märss \& Karatajūtè-Talimaa, 2002; P. klubovi Märss \& Karatajūtè-Talimaa, 2002; P. menneri Karatajūtè-Talimaa \& Märss, 2002; P. kachanovi Karatajūtè-Talimaa \& Märss, 2002; P. wilsoni KaratajūtèTalimaa \& Märss, 2002; P. readbayensis Märss, Wilson \& Thorsteinsson, 2002; $P$. kaarmisensis sp. nov.

Occurrence. East European Platform, British Isles, Severnaya Zemlya Archipelago, Greenland, Canadian Arctic Archipelago, Mackenzie Mountains; Llandovery, Lower Silurian to Lochkovian, Lower Devonian. 


\section{Paralogania martinssoni (Gross 1967)}

Plates I, II; Figure 2a-c

Holotype. Scale PMB f. 445, Museum für Naturkunde der Humboldt-Universität zu Berlin (Gross 1947, pl. IV, fig. 4).

Type locality and horizon. Vesiku Brook, Saaremaa, Estonia; Vesiku Beds, Rootsiküla Stage, Wenlock, Lower Silurian.

Material. Hundreds of scales of different preservation; the particular sample 2 TM86 from Silma cliff contains over 500 well-preserved scales.

Diagnosis. Paralogania with small scales $(0.3-0.7 \mathrm{~mm}$ in length); head scales with crenulated margins and smooth crown surface; another type of head scale with ridges and deep grooves between them continuing towards high centre or posteriorly of crown. Transitional scales crenulated anterolaterally, with flat or slightly convex crown surface, one medial spine, and two to four posterior spines on either side; spines and main crown surface on the same plane. Trunk scales with rhomboidal smooth and flat crown plate, or crown surface is ridged; scales carry up to four spines posterolaterally of crown and one medial spine beneath posterior crown apex; neck as shallow groove; anterior spur-like projection present in posterior trunk scales and in those positioned posteriorly on fins.

Description. Scales from Silma cliff are exceptionally well preserved. The specimens found include head, transitional and trunk scales, as described by Gross $(1967,1968)$, and a few new morphological varieties of scales from the head and transitional regions.

Head scales. (1) Only very few small, traquairi-type head scales are available. Their crowns are relatively high, conical, and covered with vertical ridges and grooves that converge in a peak (Pl. I, fig. 1). The scales have a roundish base, both length and width are $0.2-0.3 \mathrm{~mm}$. Sometimes the vertical ridges occur only anteriorly of the scale, while the upper surface of the crown is relatively flat (Pl. II, fig. 1). (2) Very small, complicated head scales have a length of $0.2-0.4 \mathrm{~mm}$. In most cases the crown is relatively low and the ridges converge at a slightly higher point that might be placed in the centre on the crown or backwardly (Pl. I, figs. 2, 3). Four to eight short longitudinal ridges occur anteriorly of the crown. They converge at the point from where only one ridge proceeds backwardly and forms there two or three apices (Pl. I, figs. 5, 6). Lateral ridges may form separate apices posteriorly (Pl. I, figs. 7, 8). A pair of deeper notches distinctly separates the crown into anterior and posterior portions. A ridge directed upwards and backwards arises from this lateral deep notch (Pl. I, figs. 6, 9). In some scales the upper surface of the crown is abraded and therefore smooth (Pl. I, fig. 8). The crown is just slightly longer than the base, the pulp depression is wide. Such complex scales have never been described for $P$. martinssoni (Gross).

Transitional scales (length and width $0.2-0.5 \mathrm{~mm}$ and $0.2-0.3 \mathrm{~mm}$, respectively) also have some varieties. (1) Scales traditionally treated as typical transitional scales have one medial and one to three notches anterolaterally, a smooth and 
slightly convex crown surface and spines posteriorly - one medial and up to four on both sides (Pl. I, figs. 4, 11, 12?, 18?; Pl. II, figs. 2, 5, 8). All posterior spines are placed on the same level as the crown main surface. The spines are of the same length or the medial spine is longer. (2) The main crown surface is rhomboidal, smooth and flat; a notch occurs on both sides anterolaterally; posterior spines are downstepped (Pl. II, figs. 9, 10). Pulp depression is in the centre of the base (Pl. I, fig. 10).

These two types of transitional scales were followed by trunk scales of different morphology. In the first type of trunk scale (length and width 0.3$0.5 \mathrm{~mm}$ and $0.15-0.25 \mathrm{~mm}$, respectively) the crown becomes ridged; a shallow furrow occurs between the medial and lateral ridges (Pl. I, figs. 13, 14, 22), and between the main crown area and posterolateral spines; the spines are long and sharply pointed (Pl. I, figs. 13-17, 20). Posterior spines are covered with oblique ridgelets (Pl. I, figs. 13-17, 25). A kind of channel (groove) is formed on the medial spine (Pl. I, figs. 13-17, 20). The scales may become very narrow (Pl. I, figs. 19, 21, 23-25) with one scale (Pl. I, fig. 19) possibly from a fin. The upper surface of the scale has been worn away in some cases (Pl. I, figs. 21, 23).

Another type of transitional scale leads to trunk scales with a rhomboidal smooth and flat crown plate having two to four downstepped spines posterolaterally and one posterior medial spine (Pl. II, figs. 3, 4, 6, 7). The posterior spines of some scales have double apices (Pl. II, figs. 3, 4, 14); the spines of all trunk scales have a smooth lower surface (Pl. II, figs. 11-13). The neck is distinctive as a shallow furrow. The base can be without an anterior spur (Pl. I, figs. 13, 15) or with it (Pl. I, figs. 17, 21, 22, 25) and this spur can be sometimes very long (Pl. I, fig. 24).

P. martinssoni scales from the type locality of Vesiku Brook, Saaremaa Island, are shown on Pl. II, figs. 15-25 and Fig. 2b. Typical scales of this species have a flat crown plate with $2-4$ posterolateral spines (Pl. II, figs. 23, 24). The head scales are crenulated around the crown margin or just anteriorly of it; their base can be very deep (Pl. II, figs. 15, 17). The transitional scales have two notches anterolaterally (Pl. II, fig. 20). Here we also illustrate some unusual scales to show the double apices of posterolateral spines (Pl. II, figs. 16, 18, 21, $22,25)$. The position of these scales on the body is questionable but they possibly come from the orbital region of the head. On some spines longitudinal striation is preserved (Pl. II, fig. 25). The base can be vertically rather deep; the neck is distinct (Pl. II, fig. 19).

Figure $2 \mathrm{a}-\mathrm{c}$ shows scale sets of P. martinssoni from three stratigraphically different levels: (a) from the lowest level, Ohesaare core, depth $150.5 \mathrm{~m}$; Viita Beds of the Rootsiküla Stage; (b) from the stratigraphically higher level, Vesiku outcrop, Vesiku Beds of the Rootsiküla Stage, Wenlock, and (c) from the highest level in the Kaarmise core, depth 2.9-3.1 m; Himmiste Beds of the Paadla Stage, Ludlow. Not all scale types are equally presented in the sets. The scales from the Vesiku outcrop come from a bonebed, therefore fragile scales are absent and all spines are broken. 


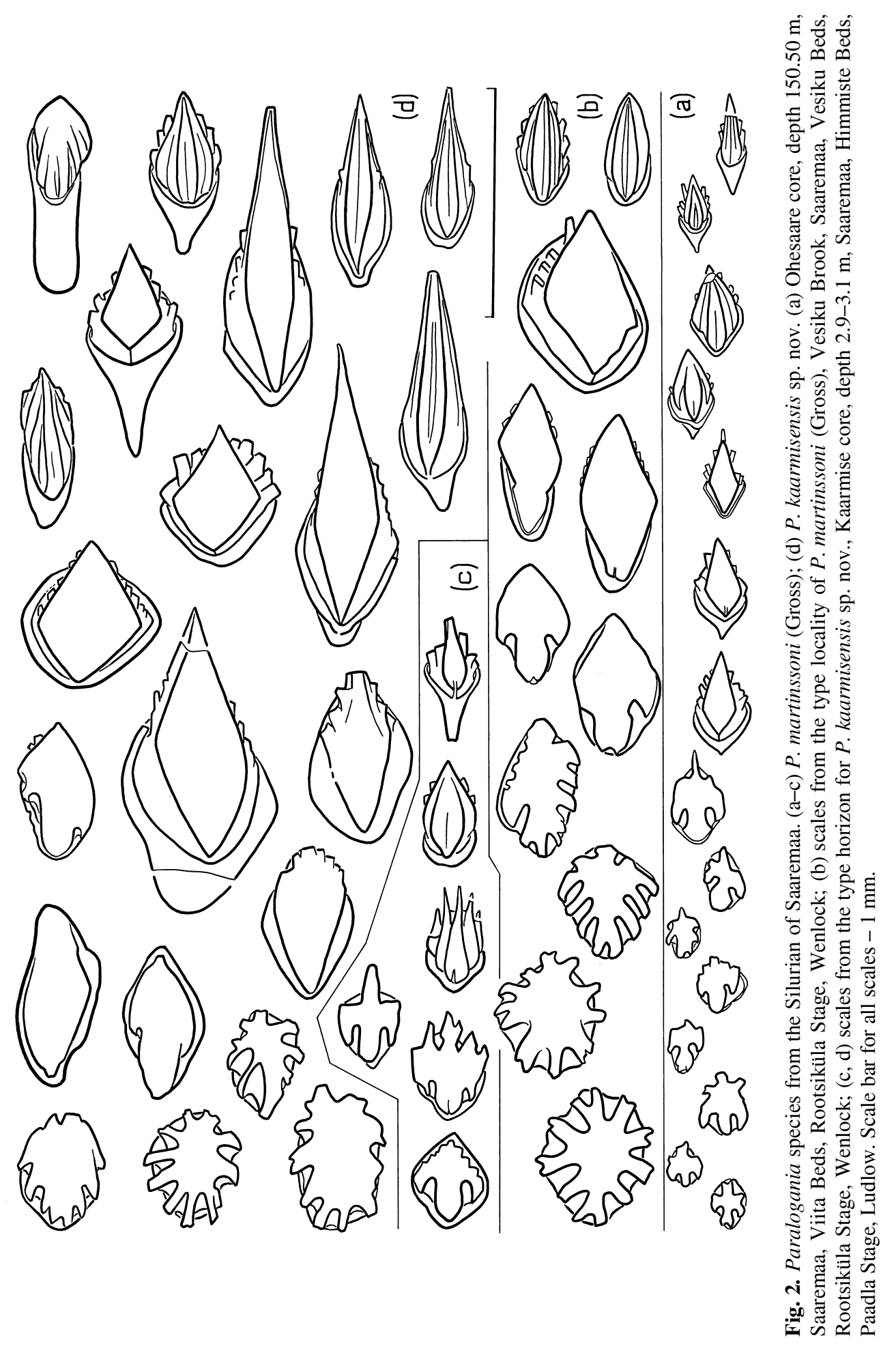




\section{Explanation of Plate I}

Paralogania martinssoni (Gross). Exceptionally well preserved scales from sample 2 TM86, Silma Cliff, Saaremaa Island; Himmiste Beds of the Paadla Stage, Ludlow, Upper Silurian.

$1-3,5-9$, head scales; $4,10,11,12$ ?, 18?, transitional scales; $13-17,19-25$, trunk scales (19 might belong to the fin region); $1,4,9$, scales in side view; $2,3,5-8,11-25$, scales in crown view; 10 , scale in base view; 14, close-up of 13; 23, close-up of 21 .

1, GIT $346-94, \times 71 ; 2$, GIT $346-58, \times 105$; 3 , GIT $346-59, \times 116$; 4, GIT $346-66, \times 93 ; 5$, GIT 346 $60, \times 82 ; 6$, GIT 346-61, $\times 70 ; 7$, GIT 346-62, $\times 87 ; 8$, GIT 346-75, $\times 76 ; 9$, GIT 346-63, $\times 83$; 10 , GIT $346-67, \times 92 ; 11$, GIT 346-76, $\times 98 ; 12$, GIT $346-77, \times 103 ; 13=14$, GIT $346-79, \times 98$, appr. $\times 168$; 15 , GIT $346-81, \times 88 ; 16$, GIT $346-83, \times 70 ; 17$, GIT $346-87, \times 91 ; 18$, GIT $346-80, \times 98$; 19 , GIT $346-90, \times 77 ; 20$, GIT $346-85, \times 71 ; 21=23$, GIT $346-91, \times 57$, appr. $\times 121 ; 22$, GIT $346-89$, $\times 64 ; 24$, GIT 346-93, $\times 54 ; 25$, GIT 346-92, $\times 60$.

\section{Explanation of Plate II}

Paralogania martinssoni (Gross). 1-14, Exceptionally well preserved scales from sample 2 TM86, Silma Cliff, Saaremaa Island; Himmiste Beds of the Paadla Stage, Ludlow, Upper Silurian. 15-25, Vesiku Brook, Vesiku Beds of the Rootsiküla Stage, Wenlock, Lower Silurian. 1, 15-18, head scales (18 may come from the orbital region); 2, 5, 8-10, 20, 21, transitional scales; 3, 4, 6, 7, 11-14, $19,22-25$, trunk scales. $1-10,16-18,20-25$, scales in crown view; 11,19 , scales in side view; 12,13 , scales in base view; 15 , scale in anterior view; 14 , close-up of $4 ; 18$, close-up of 16 ; 25 , close-up of 22 .

1, GIT 346-57, $\times 88 ; 2$, GIT 346-65, $\times 77 ; 3$, GIT 346-72, $\times 83 ; 4=14$, GIT 346-71, $\times 69$, appr. $\times 161 ; 5$, GIT $346-64, \times 78 ; 6$, GIT $346-69, \times 71 ; 7$, GIT $346-70, \times 78 ; 8$, GIT $346-78, \times 87$; 9 , GIT $346-73, \times 78 ; 10$, GIT $346-74, \times 87 ; 11$, GIT $346-88, \times 63 ; 12$, GIT $346-84, \times 91 ; 13$, GIT 346-68, $\times 78 ; 15$, GIT $346-15, \times 65 ; 16=18$, GIT $346-1, \times 86$, appr. $\times 129 ; 17$, GIT $346-3, \times 83 ; 19$, GIT $346-6, \times 74 ; 20$, GIT $346-5, \times 105 ; 21$, GIT $346-4, \times 111 ; 22=25$, GIT $346-2, \times 93$, appr. $\times 254$; 23, GIT 346-11, $\times 98 ; 24$, GIT 346-9, $\times 89$.

\section{Explanation of Plate III}

Paralogania kaarmisensis sp. nov. 1-7, 10, 11, 14-17, 20-26, 28, 29, 31, 32, Kaarmise core, depth 2.9-3.1 m; 8, 9, 12, 13, 18, 19, 27, 30, sample 1 TM86, Silma Cliff, Saaremaa Island; Himmiste Beds of the Paadla Stage, Ludlow, Upper Silurian. 1, head scale; $2-7$, transitional scales; 8-23, $30-32$, trunk scales with a smooth crown plate; $24-29$, trunk scales with one to two oblique ridges. $1-16,18-20,22-29$, scales in crown view; $17,30-32$, scales in side view; 21 , a scale in base view.

1, GIT 346-35, $\times 62 ; 2$, GIT 346-36, $\times 72 ; 3$, GIT 346-18, $\times 67 ; 4$, GIT 346-19, $\times 63 ; 5$, GIT 346-40, $\times 49 ; 6$, GIT $346-20, \times 56$; 7 , GIT $346-21, \times 54 ; 8$, GIT $346-49, \times 60 ; 9$, GIT $346-44, \times 56 ; 10$, GIT $346-32, \times 60 ; 11$, GIT $346-24, \times 35 ; 12$, GIT $346-48, \times 73 ; 13$, GIT $346-46, \times 46 ; 14$, GIT $346-31$, $\times 35 ; 15$, GIT $346-38, \times 34 ; 16$, GIT $346-29, \times 46 ; 17$, GIT $346-22, \times 43 ; 18$, GIT $346-43, \times 37$; 19 , GIT $346-45, \times 42 ; 20$, GIT $346-26, \times 34 ; 21$, GIT $346-30, \times 45 ; 22$, GIT $346-25, \times 40 ; 23$, GIT $346-39, \times 33 ; 24$, GIT $346-42, \times 35 ; 25$, GIT $346-33, \times 43 ; 26$, holotype, GIT $346-28, \times 37 ; 27$, GIT $346-50, \times 73 ; 28$, GIT $346-34, \times 53 ; 29$, GIT $346-37, \times 67$; 30, GIT 346- 47, $\times 52 ; 31$, GIT 346-27, $\times 39 ; 32$, GIT $346-41, \times 34$. 
PLATE I
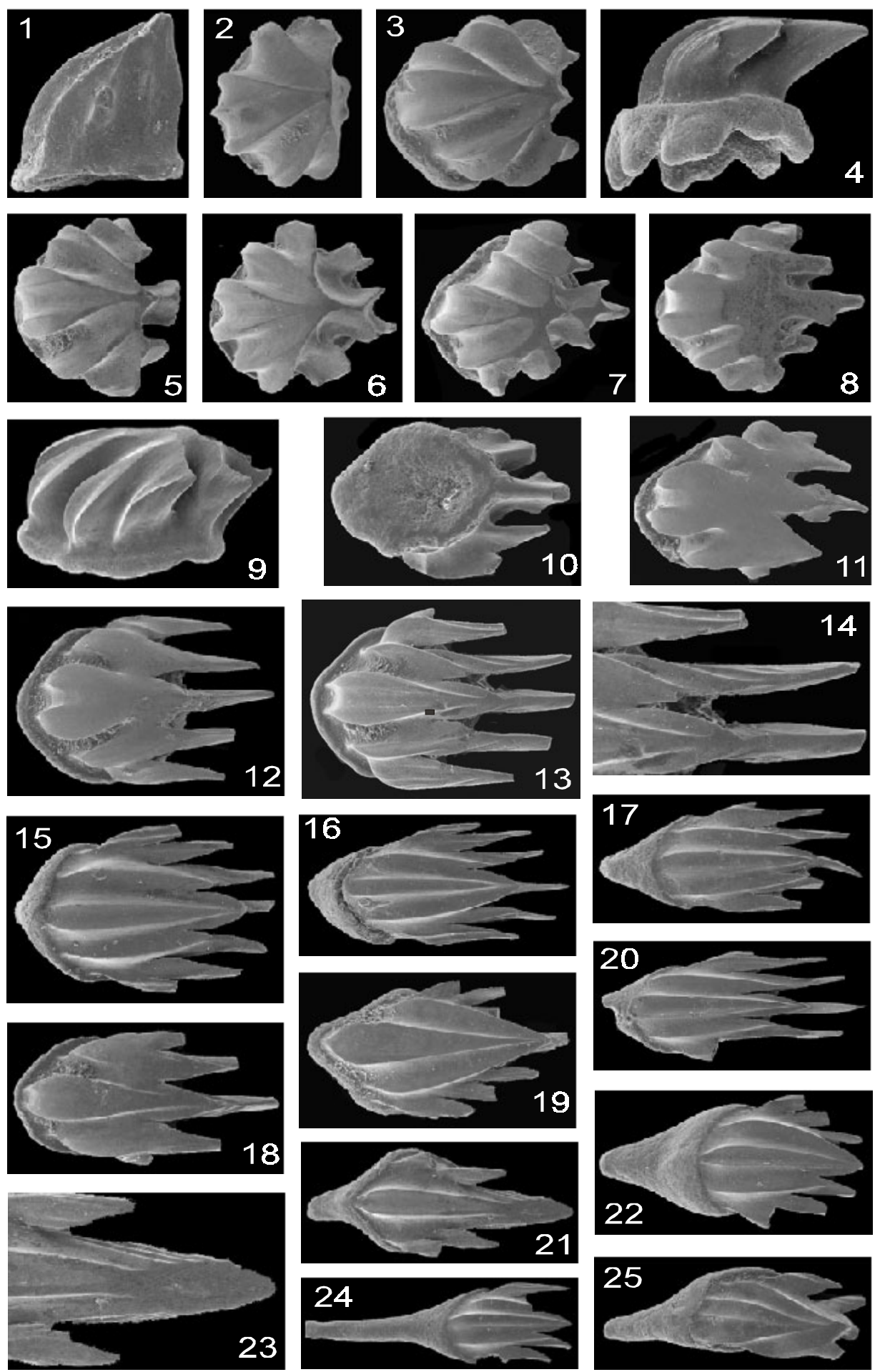
PLATE II
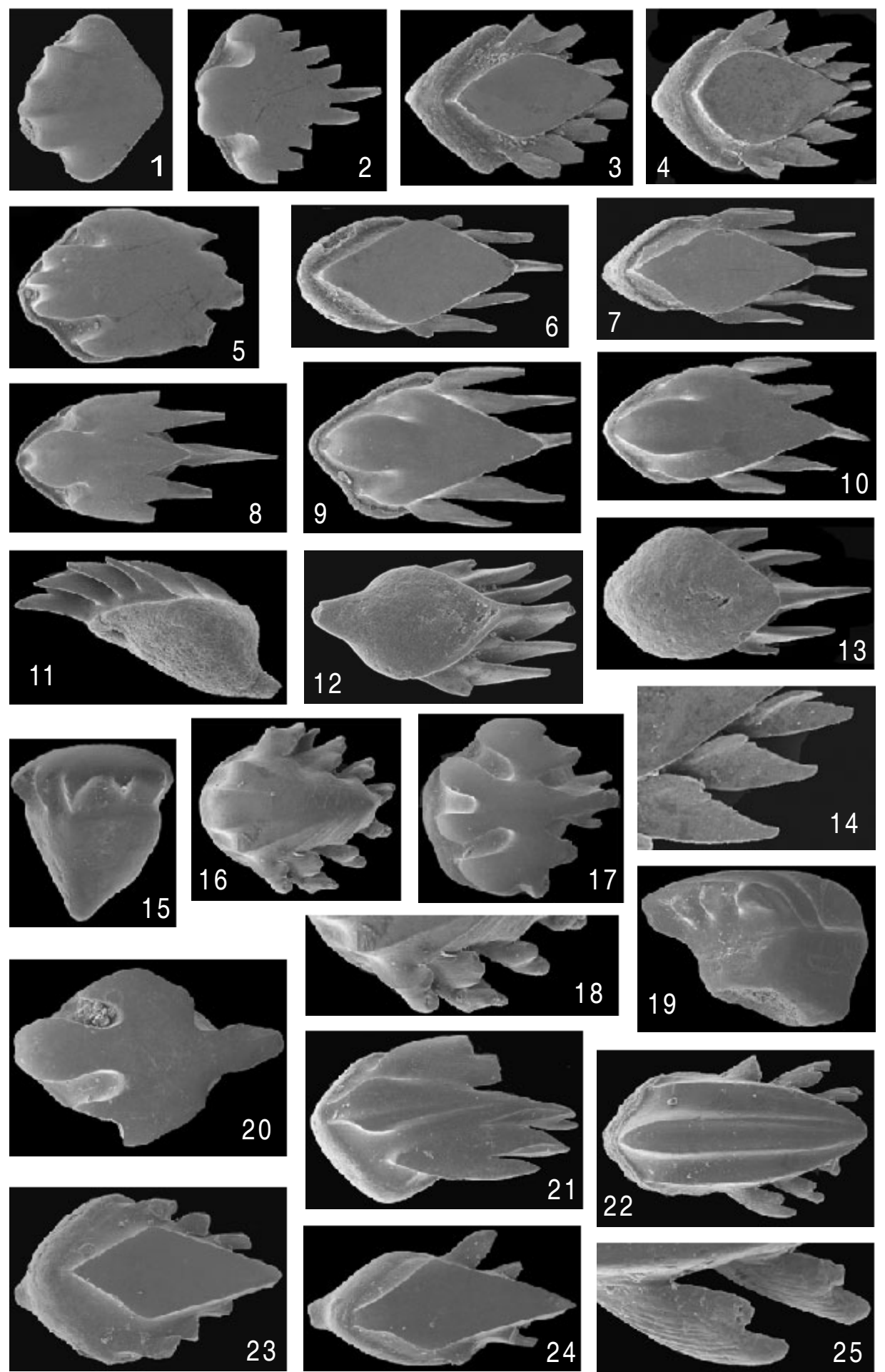

819
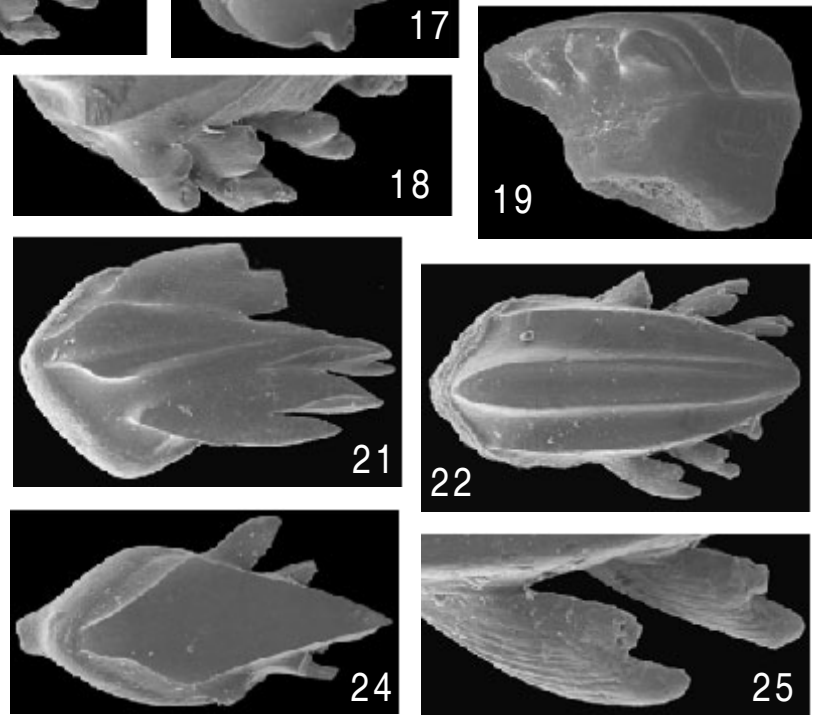

106 
PLATE III
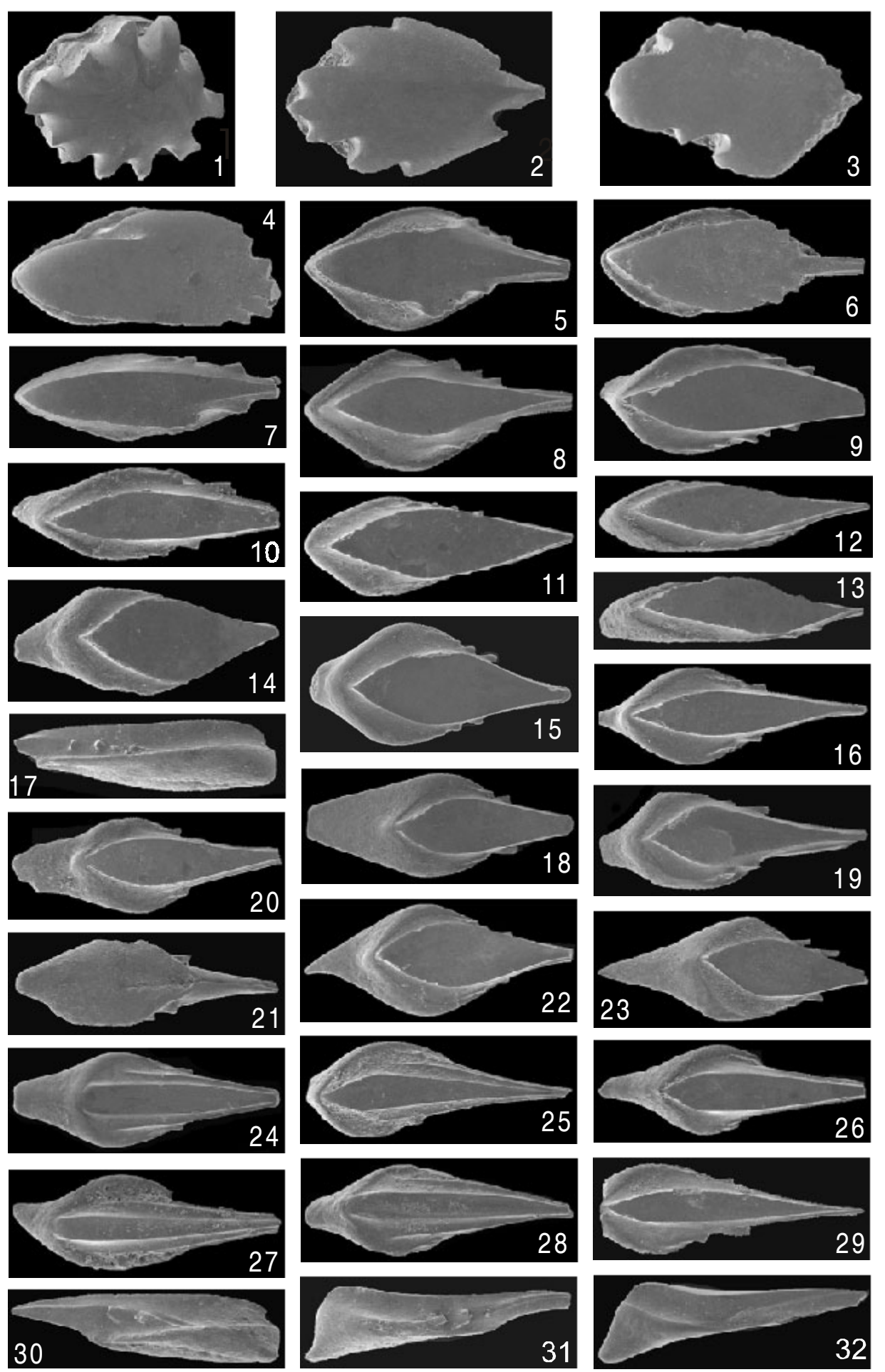
Microstructure of the scales is of sinuous dentine canals that continue upwards as relatively straight dentine tubules. Main and lateral pulp canals are present. Such appearance of canals and tubules is typical of all Paralogania species.

Comparison. See Comparison of P. kaarmisensis sp. nov.

\section{Paralogania kaarmisensis sp. nov.}

Plate III; Figure 2d

1982 Logania sp. B; Märss, fig. 2, p. 101.

1986 Logania martinssoni Gross; Märss, fig. 13: 1-5, 9?-11?, 12-15, 16?-17?, 18, 20, 22-25, 27-29, 31, non 6-8, 19, 21, 26, 30; pl. 12, figs. 13, 17, 19.

Etymology. Kaarmisensis, named after the Kaarmise core on Saaremaa Island, Estonia, where the best scales of this species come from.

Holotype. Trunk scale GIT 346-28; Pl. III, fig. 26.

Type locality and horizon. Sample at a depth of 2.9-3.1 m, Kaarmise core, Saaremaa Island, Estonia; Himmiste Beds, Paadla Stage, Ludlow, Upper Silurian.

Material. About 150 well-preserved scales from the Kaarmise-GI core, depth 2.9-3.1 m; Kuressaare-GI (= Kingissepa) core, depth 31.38-31.41 m; Himmiste982 core, depth 1.7-1.9 m; Uduvere- 968 core, depth 3.6-3.9 m, and $4.5 \mathrm{~m}$; Irase680 core, depth $6.6 \mathrm{~m}$; Silma cliff samples 1 and 2 TM86; Himmiste Beds of the Paadla Stage, Ludlow. Scales from the Varbla-502 core, depth $32.3 \mathrm{~m}$, come from the lower part of the undivided Sauvere + Himmiste beds of the Paadla Stage.

Samples from the Upper Bringewood, Gorstian, and lower part of the Leintwardine Group, Ludfordian, of Welsh Borderland (see Märss \& Miller accepted), and a sample from the Ust-Spokoinaya Formation, Ludlow, in the Matusevich River section, Severnaya Zemlya Archipelago (Karatajūtè-Talimaa \& Märss 2002, fig. 3G-I, L), contain Paralogania kaarmisensis sp. nov.

Diagnosis. Paralogania with flattened, relatively large, strongly elongate scales, with smooth crown plate or with plate having shallow furrow along midline and one to two fine, backwardly and upwardly directed ridges posterolaterally of plate; oblique ridges reach posterior crown apex; two to four, usually three, fine spines posterolaterally of crown or anteriorly of most lateral slanting ridge or beneath it; spine row does not reach posterior crown apex; double-spine beneath posterior crown apex absent; base slightly deeper anteriorly than posteriorly; pulp depression wide, as slit-like opening or smooth; pulp canal long, numerous dentine canals shorter and sinuous.

Description. In all samples Paralogania kaarmisensis sp. nov. occurs together with P. martinssoni (Gross), which makes the identification of some scales (e.g. head scales) difficult as they may belong to either of these species (Fig. $2 \mathrm{c}$ and d).

Head scales (Pl. III, fig. 1) are roundish to oval, with a rich crenulation around the crown margin. Length and width are $0.50-0.80 \mathrm{~mm}$ and $0.25-0.35 \mathrm{~mm}$, 
respectively. Short ridges and notches are directed either toward the crown centre, or in more elongate scales, to the posterior medial crown portion. The crown and the base have the same width and length. The neck is as a distinct groove. The base may carry vertical rootlets and is deeper than the height of the crown. The pulp depression is deep, with the pulp opening in the middle of the base.

Transitional scales (Pl. III, figs. 2-7) are more elongate, their length and width are $0.60-0.80 \mathrm{~mm}$ and $0.25-0.50 \mathrm{~mm}$, respectively. Two types of transitional scale were recognized: (1) The crowns of the scales with a smooth and flat or slightly convex surface and a few (1-2) notches anterolaterally on the margins (Pl. III, figs. 2-4). Such scales might have one medial and up to four spines posterolaterally of the crown; the spines are usually broken in the material available. (2) Slightly larger scales. They also have smooth and flat or slightly convex crown surface but their anterolateral crown margins form an acute angle (Pl. III, figs. 5-7), and the posterolateral margins have one medial apex and two to three spines laterally of it; anterolateral notches, if present, are very shallow. Often the crown of these scales is slightly narrower than the base. The pulp depression may be wide, occur as a longitudinal slit or be filled. The lower surface of the base is even.

Trunk scales (Pl. III, figs. 8-32) are relatively large and usually elongate, with a length and width of $0.60-1.35 \mathrm{~mm}$ and $0.45-0.70 \mathrm{~mm}$, respectively. They have a smooth crown plate, and one to four spines posterolaterally on both sides of the crown (Pl. III, figs. 8-19, 22, 23). Often a fine ridge occurs above the spines (Pl. III, figs. 12, 20, 30). The spines can also be placed at the anterior end of the oblique ridge (Pl. III, figs. 30, 31). Usually the row of spines does not reach the posterior end of the crown. The spines can be proximally vertically somewhat compressed (Pl. III, figs. 17, 30, 31), but usually they are horizontally flattened (Pl. III, figs. 16, 18, 20). In Pl. III, fig. 23, the spines are very fine and roundish in cross-section. A wide smooth area occurs between the crown and the base anteriorly of the scale (Pl. III, figs. 8-11, 14-16, 18-20, 22, 23). Trunk scales with a very narrow smooth medial plate (Pl. III, figs. 24-26, 29) and a medial longitudinal shallow furrow in it (Pl. III, figs. 27, 28) have a length and width of $0.7-1.05 \mathrm{~mm}$ and $0.2-0.25 \mathrm{~mm}$, respectively. On each side, posterolaterally of the crown, one to two longitudinal oblique ridges run up to the end of the crown joining just behind the apex of the medial plate. The most lateral ridge may have one or two spines anteriorly (Pl. III, figs. 24-27, 29) or be smooth (Pl. III, fig. 28). The fully ridged scale crowns are rare and relatively small, $0.7-0.8 \mathrm{~mm}$ long and $0.2-0.3 \mathrm{~mm}$ wide. The crown plate of trunk scales turns into a smooth shallow furrow between the plate and the base (Pl. III, figs. 17, 30-32). The base can be wide anteriorly (Pl. III, fig. 18) or with an anterior spur, which sometimes is rather long (Pl. III, figs. 22-24, 26). The pulp depression can be wide or as a narrow slit depending on the age of the scale. Often the lower surface of the crown is abraded and the pulp canal occurs as a groove up to the posterior crown apex (Pl. III, fig. 21).

Histology (see Märss 1986, pl. 13, figs. 1 and 3). The pulp canal is long, reaching the posterior end of the crown. The wall between the canal and lower 
crown surface is very thin. Numerous dentine canals arise from the pulp depression and pulp canal towards the crown surface. The dentine canals have a sinuous appearance, branching on several (five or six) levels and forming higher fine dentine tubules. Dentine tubules also occur in the spines but are absent in the anteriormost part of the scale base.

Comparison. Paralogania kaarmisensis sp. nov. is characterized by relatively large, strongly elongate, flattened trunk scales, which have a smooth crown plate or a shallow furrow along midline and slanting longitudinal ridges laterally; the scales may have either two to four very fine spines posterolaterally of the crown or beneath the most lateral slanting ridge, or a few spines (two or three) at the anterior end of the slanting ridge. Spines are nearly always situated rather anteriorly, and the posterior double-spine beneath the crown apex is absent (see also Fig. 2d). The new species differs from P. martinssoni (Gross) as it has scales that are up to three times larger. The scales are also much more elongate, with posterolateral spines that do not occur so far to the posterior as in P. martinssoni; in P. martinssoni the posteriormost spine is beneath the posterior crown apex (see also Fig. 2a-c). It differs from P. ludlowiensis (Gross) in the elongate shape of the scales, the presence of a relatively long anterior spur-like projection in many scales, and the fact that the posterolateral spines are situated rather anteriorly on the sides. P. ludlowiensis has anteriorly smoothly rounded scales, the spines occur along the whole length of the posterolateral crown walls, and the scales have a double-spine beneath the posterior crown apex. P. kaarmisensis sp. nov. scales are smaller and have fewer spines than P. kummerowi (Gross). $P$. kaarmisensis sp. nov. differs from $P$. borealis (Karatajūte-Talimaa) as it has larger, more elongate scales but both species may carry a slanting ridge above the spines. P. kaarmisensis sp. nov. has a much simpler crown than P. foliala Blom whose scales have a large flat crown with the triangular medial area carrying anteriorly one short, deep and steep medial groove; in P. foliala large lateral "wings" of the crown form at least three posteriorly pointing spines at the same level as the medial spine (Blom 1999, p. 24). Such a medial notch and lateral "wings" do not occur in any other Paralogania. P. kaarmisensis sp. nov. resembles to some extent $P$. consimilis Märss \& Karatajūtè-Talimaa whose trunk scales have a lateral oblique rib and spines beneath it and an anterior spur-like projection. Posteriorly $P$. consimilis has one simple spine (Märss \& Karatajūtè-Talimaa 2002), while $P$. kaarmisensis sp. nov. has none. The length to width ratio of P. kaarmisensis sp. nov. scales exceeds that of all other Paralogania species. Trunk scales with a wide, or a narrow and furrowed medial area are similar to those of $P$. klubovi Märss \& Karatajūte-Talimaa. The main difference in the latter is the appearance of lateral spinelets (two to three), which may occur as flat, short, widened winglets (Märss \& Karatajūtė-Talimaa 2002). The new species also differs from P. menneri Karatajūtè-Talimaa \& Märss, which has specific transitional(?) scales with a rather wide anterior half, notches anterolaterally of the crown, and a narrow and relatively long posterior "tail" or spur-like projection (Karatajūtè-Talimaa \& Märss 2002). P. kaarmisensis sp. nov. differs from 
P. kachanovi Karatajūtè-Talimaa \& Märss in the composition of lateral spines, their form and length to height ratio. P. kachanovi sp. nov. has more monolithic scales and a large number of spines (up to eight) as do P. kummerowi (Gross) and P. borealis (Karatajūtè-Talimaa \& Märss 2002). Some P. kaarmisensis sp. nov. scales have wide lateral portions of the crown of trunk scales like P. wilsoni Karatajūtè-Talimaa \& Märss, but the scales of $P$. wilsoni lack the rib above the spines which is present in P. kaarmisensis sp. nov., P. consimilis, and P. ludlowiensis (see also Karatajūtè-Talimaa \& Märss 2002). P. kaarmisensis sp. nov. is also similar to $P$. readbayensis Märss, Wilson \& Thorsteinsson as their spines are situated to anterior at or below the lateral oblique ridge, and in both there may also be two slanting ridges (Märss et al. 2002). However, P. kaarmisensis sp. nov. has relatively narrower scales than $P$. readbayensis. Other species of the genus, such as $P$. martinssoni, $P$. ludlowiensis, and $P$. kummerowi, have the series of spines forming a row extending up to the posterior crown apex while $P$. kaarmisensis sp. nov. has spines situated more anteriorly.

\section{ACKNOWLEDGEMENTS}

H. Perens, Geological Survey of Estonia, provided the samples from some cores; V. Mikli made SEM photographs and A. Ronk prepared the drawings. This study was supported by the Estonian Science Foundation (grant No. 4160). Two referees, V. Talimaa, Vilnius, and C. G. Miller, London, made very valuable comments. The help of all the above mentioned people and institutions is acknowledged.

\section{REFERENCES}

Blom, H. 1999. Vertebrate remains from Upper Silurian-Lower Devonian beds of Hall Land, North Greenland. Geol. Greenl. Surv. Bull., 182, 1-80.

Blom, H., Märss, T. \& Miller, G. 2002. Silurian and lowermost Devonian birkeniid anaspids from the northern hemisphere. Trans. Roy. Soc. Edinburgh: Earth Sci., 92, 263-323.

Gross, W. 1947. Die Agnathen und Acanthodier der obersilurischen Beyrichienkalks. Palaeontographica, 96, Abt. A, 91-161.

Gross, W. 1967. Über Thelodontier-Schuppen. Palaeontographica, 127, Abt. A, 1-67.

Gross, W. 1968. Die Agnathen-Fauna der silurischen Halla-Schichten Gotlands. Geol. Fören. Stockholm Förh., 90, 369-400.

Karatajūtè-Talimaa, V. 1978. Telodonty silura i devona SSSR i Spitsbergena. Mokslas, Vilnius (in Russian).

Karatajūtè-Talimaa, V. 1997. Taxonomy of loganiid thelodonts. Modern Geol., 21, 1-15.

Karatajūtė-Talimaa, V. \& Märss, T. 2002. Upper Silurian thelodonts of Severnaya Zemlya Archipelago (Russia). Geodiversitas, 24, 405-443.

Märss, T. 1982. Vertebrate zones in the East Baltic Silurian. In Ecostratigraphy of the East Baltic Silurian (Kaljo, D \& Klaamann, E., eds.), pp. 97-106. Valgus, Tallinn.

Märss, T. 1986. Silurian vertebrates of Estonia and West Latvia. Fossilia Baltica, 1 (in Russian with extended English summary). 
Märss, T. \& Karatajūtè-Talimaa, V. 2002. Ordovician and Lower Silurian thelodonts from Severnaya Zemlya Archipelago (Russia). Geodiversitas, 24, 381-404.

Märss, T. \& Miller, C. G. Thelodonts and distribution of associated conodonts from the Llandovery-lowermost Lochkovian of the Welsh Borderland. Palaeontology (accepted).

Märss, T., Wilson, M. V. H. \& Thorsteinsson, R. 2002. New thelodont (Agnatha) and possible chondrichthyan (Gnathostomata) taxa established in the Silurian and Lower Devonian of the Canadian Arctic Archipelago. Proc. Estonian Acad. Sci. Geol., 51, 88-120.

Miller, G. \& Märss, T. 1999. A conodont, thelodont and acanthodian fauna from the lower Př́idolí (Silurian) of the Much Wenlock area, Shropshire. Palaeontology, 42, 691-714.

Nestor, H. \& Einasto, R. 1997. Ordovician and Silurian carbonate sedimentation basin. In Geology and Mineral Resources of Estonia (Raukas, A. \& Teedumäe, A., eds.), pp. 192-204. Estonian Academy Publishers, Tallinn.

Soehn, K. L., Hanke, G. F., Märss, T. \& Wilson, M. V. H. 2000. Preliminary vertebrate biostratigraphy of the Avalanche Lake sections (Wenlock, Silurian), southern Mackenzie Mountains, N.W.T., and review of northwestern Canadian vertebrate localities of Silurian Age. In Palaeozoic Vertebrate Biochronology and Global Marine/Non-Marine Correlations. Final Report of IGCP 328 (1991-1996) (Blieck, A. \& Turner, S., eds.). Courier Forschungsinst. Senckenberg, 223, 129-156.

Suuroja, K., Vingissaar, P. \& Tomberg, U. (compilers). 1997. Geological map of Estonia. Geological Survey of Estonia.

\section{Paralogania Rootsiküla (Wenlock) ja Paadla (Ludlow) lademest Eestis}

\section{Tiiu Märss}

Artiklis vaadeldi kahe Paralogania liigi soomuseid Rootsiküla (Wenlock) ja Paadla (Ludlow) lademest Saaremaalt. Kirjeldati erakordselt hästi säilinud P. martinssoni (Gross) soomused Paadla lademe Himmiste kihtidest Silma panga läbilõikest ja võrreldi neid selle liigi soomustega tüüpleiukohast Vesiku ojalt Rootsiküla lademest. Uus liik $P$. kaarmisensis sp. nov. eraldati $P$. martinssonist tunduvalt suuremate ja piklikumate soomuste põhjal, mis kannavad väga peeni ogakesi krooni külgedel, kas viltuselt taha üles kulgeva kõige välimise ribi ees või selle all; ribisid võib olla 1-2. Uus liik levib kitsas intervallis Phlebolepis elegans'i biotsoonis Ludlow's Ülem-Siluris. 